best be ensured.

The panel, which ideally should come up with preliminary conclusions before the end of the year, would also look into possibilities of setting up a European telecommunications body, placed under Commission authority. Commission sources admitted the ideas were given "a lukewarm reception" by Community governments.

Better received, and less radical, were Davignon's ideas on biotechnology. Davignon pleads for an extension of the 1982 programme, which was focused on agriculture and food, to the health sector. Research would again be equally financed by the Commission and by European industry.

But Davignon's ideas once again exceed the narrow framework of research and development. For Davignon, industry's access to raw materials must be improved. But Community governments are unlikely to follow Davignon on this point: opening up the market to imports of cheap farm produce like starch, a basic requirement of the biotechnology industry, would upset the already fragile and politically sensitive Common Agricultural Policy.

Geert Linnebank

\section{Europe and US to fuse on fusion?}

\section{Brussels}

THE European Commission wants to develop transatlantic cooperation in research on thermonuclear fusion and has asked member states for permission to negotiate a formal cooperation agreement with the US Administration.

A spokesman for the Commission said the US authorities had welcomed plans to exchange information and staff working on tokamak confinement vessels, alternative magnetic confinement technologies and inertial technology.

The idea of this cooperation was first launched on the eve of the Versailles Western economic summit in talks between Research Commissioner Etienne Davignon and President Reagan's scientific adviser, George Keyworth. A tentative agreement to institutionalize it was reached in March, but Community member states have yet to endorse the plan.

Europe currently leads the field in research on fusion reactors based on the magnetic plasma confinement principle, generally thought to be the most promising approach. Approximately 90 per cent of Europe's fusion research resources are invested in the development of the Culhambased Joint European Torus (JET) giant tokamak, which is expected to become operational later this year, and related projects. But Europe lags behind the United States in alternative technologies and fuel (tritium) handling.

Geert Linnebank

\title{
Polychlorinated biphenyls in human tissue
}

A REPORT published recently by the US Environmental Protection Agency on the levels of polychlorinated biphenyls (PCBs) in human adipose tissue shows that while almost all Americans now have detectable levels of the compounds in their tissues, very few have above the 3 parts per million (p.p.m.) level arbitrarily designated by the report as "high". The figure clearly shows the impact of the regulatory legislation that was introduced in 1976 controlling the "manufacture, processing or distribution" of PCBs. Before this date the number of people with "high" levels had been steadily increasing, but since 1976 this level has dropped dramatically so that now only one per cent of Americans have PCB levels above 3 p.p.m.

The report lists two caveats - first that the survey was conducted on cadavers which may not be representative of the general population, and second that only urban populations were investigated. Since much of the controversy over PCBs has involved their inclusion in herbicides this second proviso may mark a significant shortcoming.

The increase in background levels of $P C B$ in adipose tissue, and, to a lesser extent, in human milk, is due at least partly to their use in electrical equipment, chlorinated hydrocarbons being used as a dielectric in transformers and capacitors.

Dr F. Kutz, head of the field department on whose data the report was based, believes that "as a result of certain exemptions from the 1976 Toxic Substance Control Act around 600 million pounds of PCBs are still in existence, either in storage or in electrical appliances".

Melanie Kee

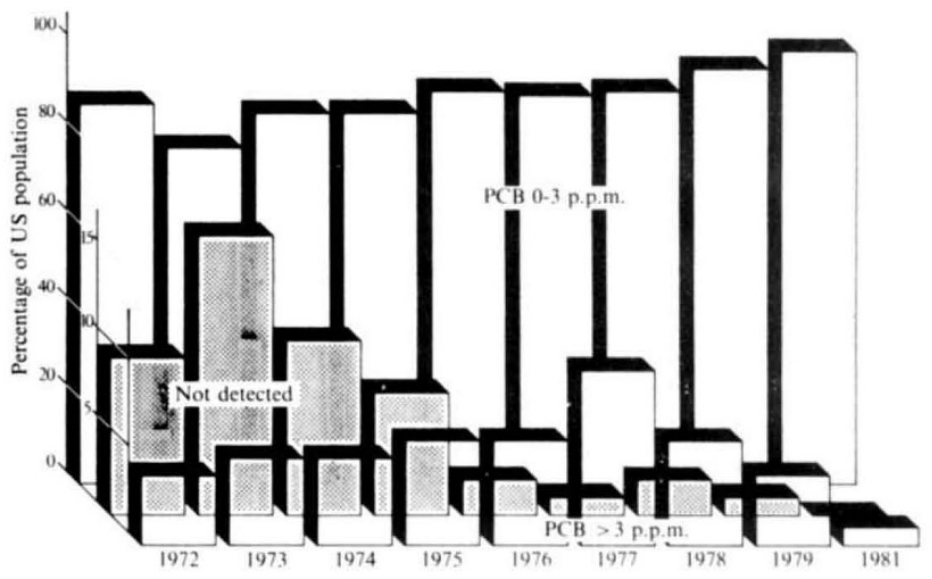

\section{Czechoslovakia}

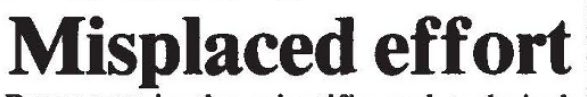

PROGRESS in the scientific and technical development of the country was reviewed in last week's meeting of the Communist Party of Czechoslovakia. The official report, delivered by Presidium member Milos Jakes, painted a gloomy picture, the "key problem" being the "slow and inadequate" implementation of research results in practice. Shortly before the meeting, however, the party daily Rude Pravo had come up with a new explanation of the lag - inefficient deployment of funds.

According to Rude Pravo, the excuse most often proffered by industrial enterprises failing to innovate is that of insufficient funds. However, it went on, a recent survey by the finance ministry had found that some 200 to 300 million crowns a year (£12.5-£19 million) set aside for research and development is going unspent. Often, it appears, the funds are not made available on time so that the planned innovation cannot be started. On the other hand, and particularly when the development programme has not been properly prepared, "random actions" occur, with funds being misappropriated and diverted to purposes "which have nothing to do with research and development". Sometimes, Rude Pravo noted, the funds have been spent on developments whose ultimate economic benefit has never been established.

This somewhat novel criticism found only a brief echo in Jakes' presentation to the party meeting: a call for the better use of the 19,000 million crowns ( $£ 1,200$ million) annually allotted to developing science and technology (4 per cent of the national income) to be concentrated on the "most decisive tasks" (including energy-saving technologies, microelectronics, the chemical industry and biotechnology).

Both Rude Pravo and Jakes suggested that most of the problems could be overcome with better labour discipline, but while the paper called for "the more consistent application of sanctions" to enterprises where there were shortcomings, Jakes concentrated on building up the research base with properly-motivated cadres, the need for better designers, technologists and development engineers, and the need to improve "moral" and financial incentives.

Vera Rich 